\title{
Does Output Gaps Matters for Inflation Forecast in Nigeria?
}

\author{
Aliyu Alhaji Jibrilla ${ }^{1 \& 2}$, Haruna Muhammad Dodo ${ }^{3}$ \\ ${ }^{I}$ Ph.D. Candidate, School of Graduate Studies, Universiti Putra Malaysia \\ ${ }^{2}$ Department of Economics, Faculty of Arts, Social and Management Sciences, Adamawa State University, \\ P.M.B. 25 Mubi, Adamawa State, Nigeria \\ ${ }^{3}$ Department of Banking and Finance, College of Administration and Business Studies, Adamawa State \\ Polytechnic, P.M.B. 2146, Yola, Adamawa State, Nigeria
}

\begin{abstract}
This paper empirically examines the role of output gaps in determining future inflation rate, and the extent real output deviations will be accounted for by changes in real interest rate in Nigeria. The study revealed that the actual behaviour of the central bank in Nigeria place little importance on deviations of real income relative to inflation changes. Generally, for the case of monetary transmission mechanism effect on the real output, our findings suggest that the behaviour of the monetary policy instruments have no significant effect on the deviations of real economy from its potentials. These findings suggest that monetary policy committee of the central bank should consider strategies that can enhance public confidence and support.
\end{abstract}

Keywords: monetary policy, output gaps, inflation rate, real interest rate, inflation targeting, central bank

\section{Introduction}

In principle, monetary policy could greatly influence, at least in the short-run, changes in the general price levels and demand for goods and services in an economy (see Bernanke \& Gertler, 1995). Hence, central Banks often control inflation by altering a short-term/overnight interest rate, often referred to as policy rate. Until the late 1980s, central Banks (CBs) around the world use the conventional approaches of inflation control. These approaches which include exchange rate targeting and monetary targeting involved the use of nominal interest rate by the CBs to maintain price stability, and hence stable economic growth. However, since the early 1990s, many countries around the globe have shifted to inflation targeting (IT) regime as an alternative policy rule to maintain economic stability (Siklos \& Weymark, 2009). IT is a policy in which the CB explicitly publicizes its goal target for inflation rate, and then make an effort to steer actual inflation towards 'targeted rate', usually via interest rate changes. "This approach is characterized by announcement of official target ranges for the inflation rate at one or more horizon, and by explicit acknowledgement that low and stable inflation is the overriding goal of monetary policy" (Bernanke \& Mishkin, 1997, p. 97). This framework has been widely seen to be useful for countries that have adopted and practice it, most of whom are from advanced and semi-advanced nations (Savastano, Masson, \& Sharma, 1997; Mishkin, 1999, 2001, 2005; Svensson, 2010).

Most of the countries that practice IT are from high income countries, although, recently, some few African countries such as South Africa and Ghana have joined the league (Savastano et al., 1997; Mishkin, 2001). Among the major considerations to be made for a successful switch to inflation targeting regime include whether government have more emphasis on Seigniorage as a sources of its revenue and/or less concern is given to achieving low inflation in an economy, a situation that may likely happen in a country where central bank lacks independency (see Savastano et al., 1997; Svensson, 2010). If an important part of public finance constitutes Seigniorage or when there is less concern or lack of proper inflation forecasting model in an economy, inflation targeting may not be an ideal monetary policy framework (Kadioğlu, Özdemir \& Yilmaz, 2000). However, as noted by (Svensson, 2010), absence of formal central bank independency may not necessarily hinder the success of inflation targeting in achieving the monetary policy goals such as stabilizing prices, and other traditional stabilization objectives that include minimizing fluctuations in employment and output.

In Nigeria, with the adoption of monetary targeting following the collapse of Bretton woods in 1973, the CBN has been directed with the objective of achieving price stability and sustainable economic growth. However, since the inception of this framework, the CBN has been exposed to fluctuations in its monetary aggregates (Ojo, 2013), and thus finds itself in difficult situation to achieve low inflation rate. The historical fluctuations of monetary aggregates in the country have highlighted an inquiry on the credibility of monetary targeting as well as the accountability of the central Bank in the conduct of monetary policy. Monetary targeting strategy therefore appears not to be an option for Nigeria. Thus the country may look to other monetary policy regime, one of which is inflation targeting (IT). Svensson (2000), however, asserts that the appropriate objective of monetary policy of any central bank should involve both "stabilizing inflation and the real economy", often represented by "out put gaps". 
In this paper, given the Svensson's claim, and as well, reflecting to the central bank's consideration to shift its monetary policy strategy to full fledge inflation targeting (see Ojo, 2013), we want to increase public understanding of the central bank's behaviour with regard to the conduct of monetary policy. In particular, our main goal is to evaluate how central bank of Nigeria practically reacts to both inflation changes and output deviations. To achieve this goal similar to Rudebusch and Svensson (1999), we use lose function inflation targeting model that involve minimizing deviations of actual inflation from the projected inflation rate or explicit inflation target. Our study also intent to evaluate the extent to which output deviations can provide a practical guide for inflation forecasting in the country. Our models as in Rudebusch and Svensson focus on monetary policy rate as the central bank 'operating target' or policy instrument (assuming no direct effect of monetary aggregates). The model is also specified in terms of deviations from potential output from trends (often referred to as 'output gaps'). In addition, the model includes Philips curve with "autoregressive expectations" in line with 'natural rate hypothesis', which is based on the proposition that money growth rate has long-run neutral effect on the unemployment rate, irrespective of inflation rate (see for example, Cross, 1995; Salemi, 1999).The rest of the paper is organized as follows: the next section briefly reviews monetary policy experience in Nigeria; section 3 expresses empirical models,; section 4 describes estimation method and data; section 5 presents and discusses the empirical findings and; finally, section 6 concludes.

\section{Brief Experience Of Monetary Policy Frameworks In Nigeria}

Since its inception in 1958, the dominant strategies used by the central bank of Nigeria in the conduct of monetary policy were exchange rate targeting (or exchange rate peg) and monetary targeting. Before the failure of Bretton Woods's system in 1973, the key strategy used by the central bank of Nigeria (CBN) in the implementation of its monetary policy was the exchange rate targeting relative to the British pound, which was the anchored currency for the Nigerian pound. However, following the breakdown of the parity between Nigerian pound and that of British due to depreciation of the British pound in the late sixties (60s), the new Nigerian currency (the naira) was pegged to American dollar as its 'anchor currency' (Ojo, 2013). Then in 1970, in response to the demolishing of Bretton Woods, monetary targeting has been the CBN's policy strategy (CBN, 2011a).

Monetary targeting regime usually entails using monetary aggregates as an intermediate target (Mishkin, 2005). It contains three components that include dependence on information conveyed by monetary aggregates for the conduct of monetary policy; target declaration for monetary aggregates; and some degree of central bank accountability that can prevent regular and substantial deviation from the monetary targets (Mishkin, 2001). Following for example, the United States Federal Reserve Bank and the Bank of England, the central Bank of Nigeria responded to rising inflation and introduced monetary targeting in 1974. Under this policy, the CBN targets the growth in money supply, mainly to ensure long-term stability of domestic prices and external balance (CBN, 2011a, 2011c).

However, it appears that this change in CBN's policy approach did not produce the desired results for goal variables such as inflation and sustainable income growth. For example, through the periods of 2000-2009, the central bank of Nigeria could not restrain fluctuations in all the monetary aggregates. During these periods, although, it was only in 2004 that the CBN missed its growth targets of broad money (M2) and narrow money (M1) supply respectively, the net domestic credit in the year 2000, 2002 and 2004-2005 were below the Bank's targets. A similar pattern was recorded for credit to private sector in 2002, 2003 and 2009 (Ojo, 2013). In addition, it has also been noted for the period of 1996 to 2006 by Mordi (2008) and Uchendu (2008) in Ojo (2013) that the velocities of both base and broad money have recorded wide fluctuations. This may suggest that monetary aggregates could not be a useful guide for the conduct of monetary policy in Nigeria. Thus, under this circumstance, monetary policy will not guarantee inflation expectations and stable growth in income, thereby undermining the assessment of the CNB's accountability (see, Mishkin, 2001). In addition, according to Mishkin (2001), "an unreliable relationship between monetary aggregates and goal variables makes it difficult for monetary targeting to serve as a communications device that increases the transparency of monetary policy and makes the central bank accountable to the public"(p. 8).

Given the above situation, one wonders what would be an ideal monetary policy framework for the central bank of Nigeria. The subsequent sections of this study are devoted towards providing useful guide for future monetary policy strategy in the country.

\section{Empirical Models}

Following Rudebusch and Svensson (1999) and Gerlach and Smets (1999) among others, we specify the following linear inflation forecasting and output gaps models

$$
\pi_{t+1}=\alpha_{0}+\sum_{i=1}^{n} \alpha_{i} \pi_{t+1-i}+\beta_{1} y_{t}^{*}+\varepsilon_{t+1}^{\pi},
$$




$$
y_{t+1}^{*}=\sum_{i=1}^{m} \beta_{1+i} y_{t+1-i}^{*}-\beta_{M+1}\left(i_{t}-\bar{\pi}\right)+\varepsilon_{t+1}^{y^{*}} \text {, }
$$

Where, $\pi_{\mathrm{t}}$ denotes year on year inflation rate, based on consumer price index 1995. $i_{\mathrm{t}}$ represents average annual central bank policy rate (average nominal interest rate), such that $\left(i_{t}-\bar{\pi}\right)$ represents Nigerian real interest rate for the period under review, $y^{*}$ is the log of gaps between the real GDP and the unobserved potential real GDP, $n$ and $m$ represent the number of lags of inflation and to a lagged output gaps ${ }^{1}$ respectively. $\varepsilon^{\pi}$ and $\varepsilon^{y^{*}}$ are independently and identically distributed shocks with zero mean(s) and constant variance(es). The inclusion of output gaps in the model is based on the assumption that it should contain information which regards to future inflation (see Razzak \& Dennis, 1999).

Equation (1) represents how inflation relates to its own lag(s) and to a lagged output gaps. The lagged or lags of inflation represent(s) 'inflation expectations'. Equation (2), on the other hand, shows how output gaps relates to its own lags and to difference between average central bank policy rate and average annual inflation rate, which represents monetary transmission mechanism ${ }^{2}$.

\section{Estimation Method And Data}

Given the time series nature of our data, we employ ordinary least square (OLS) to estimate eqns. (1 \& 2). However, before the estimations, we start with determining the integrating order of our series variables. Accordingly, we perform stationarity tests using Augmented Dickey-Fuller (ADF) and Philips Perron unit root tests. This is followed by cointegration test using Eagle granger, which is based on two step procedures that involves estimating the long-run equilibrium equation $1 \& 2$ whose residuals will then be estimated to establish long-run equilibrium between cointegrated series. This involve estimating (3) which focus on the estimates of $\rho$ and $\varpi$.

$$
\Delta \hat{\varepsilon}_{t}=\rho \hat{\varepsilon}_{t-1}+\sum_{i=1}^{p} \varpi_{i} \Delta \hat{\varepsilon}_{t-j}+v_{t}
$$

The null hypothesis of no cointegration is specified as: $\rho=0$. Rejecting this null hypothesis implies that the residuals $\varepsilon_{t}$ in equation one is white noise. Eqn. 3 describes how the explained and explanatory variables in eqns. $1 \& 2$ behave in the short-run consistent with the long-run cointegrating relationship..

Data used in this study are annual time series: average year on year inflation rate, average annual central bank policy rate, and output gaps (proxies by deviation of real GDP from potential GDP) for the period of 19612012. Averages of inflation and central bank policy rates are obtained from the Statistical Bulletin: Golden jubilee edition of the central Bank of Nigeria (CBN, 2008), and the CBN online database ${ }^{3}$. The real GDP variable has been collected from the online database of the world development indicators (WDI) (World Bank, 2013).

\subsection{Unit root and Eagle-Granger cointegration tests}

\section{Empirical Findings}

Following the conventional practice, we conduct stationarity tests on variables of interest. This test results are reported on table 1.

\begin{tabular}{|c|c|c|}
\hline $\begin{array}{l}\text { Variable } \\
\pi_{t}\end{array}$ & $\begin{array}{ll}\text { ADF test } & -4.09 * *[0]\end{array}$ & PP test \\
\hline$\Delta \pi_{t}$ & $-9.09 * * *[0]$ & $-9.14 * * *[1]$ \\
\hline$y_{t}$ & $-.84[0]$ & $-1.23[3]$ \\
\hline$\Delta y_{t}$ & $-5.06^{* * *}[0]$ & $-5.01 * * *[3]$ \\
\hline
\end{tabular}

Table 1. Results of the ADF and PP Unit Root Tests (1961-2012)

${ }^{1}$ The series of our output gaps were obtained based on the method advanced by Hodrick-Prescott (1997). The effectiveness of monetary policy transmission mechanism (MPTM) may, however, depend on the structure of an economy. For the case of Nigeria that heavily depends on primary product exports (see Jibrilla, 2010), the MPTM may likely exhibit weaker effect on the real economy.

${ }^{2}$ See Rudebusch and Svensson (1999).

${ }^{3}$ Retrieved on 09/10/2014 from http://www.cenbank.org/ 


\begin{tabular}{lll}
\hline$i_{t}$ & $-2.53[0]$ & $-2.39[3]$ \\
$\Delta i_{t}$ & $-7.50^{* * *[1]}$ & $-9.56^{* * *[3]}$ \\
\hline Eagle-Granger Cointegration tests & & \\
$\rho_{1}^{\pi}-7.058^{* * *}(-2.615)$ & & \\
$\rho_{1}^{y_{t}^{*}}-7.393^{* * *}(-2.613)$ & & \\
\hline
\end{tabular}

Note: Numbers in square brackets are lag lengths used in the ADF test (as determined by Schwarz information criteria (SIC)) to remove serial correlation in the residuals, they (numbers in square brackets) represent Newey-West bandwidth. Numbers in parentheses are critical t-statistics. $* * *$ and $* *$ denote rejection of the null hypothesis at the 1 and 5 per cent significance levels respectively. . Entries of $\rho_{1}^{\pi}$ represents long-run cointegrating relationship between variables in model (1), while entries of $\rho_{1}^{y_{t}^{*}}$ denotes long-run relationships between variables in model (2)

The Augmented Dickey-Fuller (ADF) and Phillips Perron (pp) unit root tests for the null hypothesis of unit root in the series is tested against the alternative hypothesis of stationarity. The results of the unit root tests revealed that except the average inflation rate, both real GDP and nominal interest rate series are non-stationary at their levels. However, the first differences of all the series are statistically significant. Since the unit root tests clearly indicate that all variables are stationary at first difference, that is, I(1), they should therefore appear in the multivariate Eagle Granger (EG) cointegration test. Results from EG cointegration tests indicate long-run and stable relationships among the variables included in both models $1 \& 2$. This therefore allows examining the actual long-run relations among our variables of interest.

Due to the fact that the reliability of our findings to draw any inferences will depend on the robustness of the estimated coefficients, we have conducted various diagnostics tests. The residual diagnostics tests for both serial correlation and heteroskedasticity failed to establish any case of departure from the standard assumptions. Moreover, the stability diagnostic test for functional form also shows that the models are correctly specified.

$$
\begin{aligned}
& \pi_{t+1}=-16.91+.56^{\mathrm{a}} \pi_{t}+.025 \pi_{t-1}-.066 \pi_{t-2}+.047 \pi_{t-3}+17.05 y_{t}^{*}+\varepsilon_{t+1}^{\pi} \text {, } \\
& \begin{array}{lllll}
(43.01) \quad(.149) & (.164) \quad(.164) \quad(.145) \quad(28.97)
\end{array} \\
& \mathrm{R}^{2}=.30, \mathrm{DW}=2.06, \mathrm{LM}=1.714[.424], \mathrm{BPG}=5.998[.306], \mathrm{CH}=3.613[.164], \mathrm{RRT}=3.923[.0544]^{5} \text {, } \\
& y_{t+1}^{*}=.85+.85^{\mathrm{a}} y_{t}^{*}+.42^{\mathrm{a}} y_{t-1}^{*}-.007\left(i_{t}-\bar{\pi}\right)+\varepsilon_{t+1}^{y_{t}^{*}}, \\
& (.178)(.132) \quad(.133) \quad(.00) \\
& \mathrm{R}^{2}=.49, \mathrm{DW}=2.09, \mathrm{LM}=4.153[.125], \mathrm{BPG}=2.196[.533], \mathrm{ARCH}=.559[.756], \mathrm{RRT}=3.631[.063] \text {, }
\end{aligned}
$$

Estimated results for models (1\&2) are reported in eqns. (4) and (5) respectively. From equation (4), it can be observed that only the first autoregressive inflation parameter is statistically significant in explaining the subsequent inflation rate. The coefficient of the output gaps indicated that deviations of real output from its potential has insignificant effect on subsequent inflation in Nigeria for the period under review. In addition, estimates of eqn. (2) indicate that both the first-order and the second-order autoregressive -coefficients of output gaps are significant in explaining succeeding real out deviation in Nigeria. However, the coefficient of the real interest rate suggests that output gaps are non-sensitive to real domestic interest rate for the period under review.

\footnotetext{
4 ' $a$ ' denotes $1 \%$ level of significance

5 LM is the Breusch-Godfrey LM test for Serial Correlation; BPG is the Breusch-Pagan-Godfrey Heteroskedasticity test; $\mathrm{CH}$ is the ARCH Heteroskedasticity test for the ARCH effect; RRT is the Ramsey RESET Test for functional form.
} 


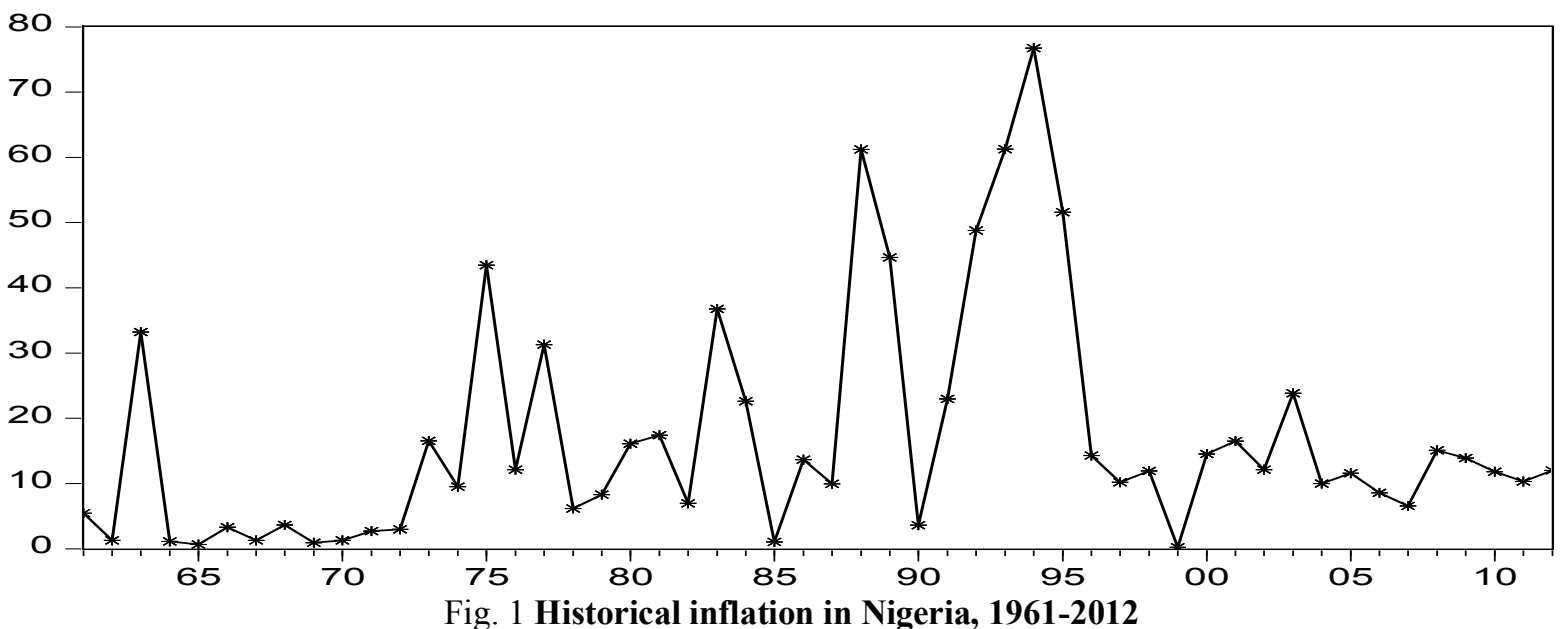

These findings seems to suggest that the central bank's behaviour is more of 'inflation reaction', perhaps, partly to prevent future occurrence of higher inflation rate such as those happen during the Structural Adjustment Programme (SAP) implementation era, particularly, in the late 1980s and early 1990s. During these periods, as can be observed from "Fig." 1, Nigeria recorded its highest historical inflation rates which are likely to be poorly captured by the central bank's policy rate. In fact, as shown above, central bank's action in the current period has only significant effect on a year's term inflation. A likely justification is that the CBN cares more to inflation relative to output deviations and reacts to its deviations. It is also worth noting from the result obtained by the second model (2) that the non-sensitivity of output deviations from changes in real interest rate seems to justify the earlier finding, which indicate likely trade-off between inflation and other monetary policy goals such as output deviations and/or unemployment levels. Although, assessing the transparency of banking system in Nigeria is outside the scope of this study, the inability of the real interest rate to have elasticity effect on real output deviations may imply that monetary policy transmission mechanism in Nigeria have weak effect on the real economy, and may as well be suggestive to inadequate transparency in the banking industry6.

\section{Conclusion And Policy Implications}

This study empirically evaluates whether output gaps significantly influence inflation forecast in Nigeria. Our results provide evidence for non-sensitivity effect of real output deviations on future inflation rate in the country. We also found that the real interest rate, which represents monetary transmission mechanism, has no significant effect on the output gap elasticity.

These findings have important implications in terms of the Nigerian central bank's effort towards full fledge inflation targeting. In spite of the perceived achievements recorded by the bank since the late 1990s (as can be observed from figure 1), the central bank monetary policy committee needs to strengthen central bank's operational transparency and accountability. This could be achieved by making public, how macroeconomic policy goals are achieved, and how unexpected macroeconomic shocks affect their policy goals, and as well, how they overcome them. This is particularly important, because through transparency and accountability, CB can gain more public confidence, and hence more support. Not only the government, public should also be consistently provided with information regarding the conduct of monetary policy that has direct effect on their lives, especially on unemployment and inflation issues.

\section{References}

[1] Adeyemi, B. (2011). Bank failure in Nigeria: a consequence of capital inadequacy, lack of transparency and non-performing loans?. Banks and Bank Systems, 6(1), 99-109.

[2] Bernanke, B. S., \& Gertler, M. (1995). Inside the Black Box: The Credit Channel of Monetary Policy. The Journal of Economic Perspectives, 9(4), 27-48.

[3] Bernanke, B. S., \& Mishkin, F. S. (1997). Inflation Targeting: A New Framework for Monetary Policy?. The Journal of Economic Perspectives, 11(2), 97-116.

[4] CBN (2008). Statistical Bulletin: Golden jubilee Edition. Central Bank, Abuja, Nigeria.

[5] CBN (2011a). Understanding monetary policy Series No. 1. Central Bank, Abuja, Nigeria.

[6] CBN (2011c). Understanding monetary policy Series No. 3. Central Bank, Abuja, Nigeria

[7] Cross, R. (Ed.). (1995). The natural rate of unemployment: reflections on 25 years of the hypothesis. Cambridge University Press.

\footnotetext{
${ }^{6}$ See for example Adeyemi (2011).
} 
[8] Gerlach, S., \& Smets, F. (1999). Output gaps and monetary policy in the EMU area. European Economic Review, 43(4), 801-812.

[10] Hodrick, R. J., \& Prescott, E. C. (1997). Postwar US business cycles: an empirical investigation. Journal of Money, credit, and Banking, 1-16.

[11] Jibrilla, A.A. (2010). Savings and Domestic Investment in Nigeria: A causal relationship. ADSU Journal of Social and Development Studies, 4(1), 112-121.

[12] Kadioğlu, F., Özdemir, N., \& Yilmaz, G. (2000). Inflation targeting in developing countries. The Central Bank of the Republic of Turkey, Discussin Paper.

[13] Mishkin, F. S. (2001). From monetary targeting to inflation targeting: lessons from industrialized countries. World Bank, Financial Sector Strategy and Policy Department.

[14] Mishkin, F. S. (2005). Monetary Policy Strategy: The International Experience. Accessed on 4/10/2014 at http://home.cergeei.cz/pstankov/Teaching/VSE/Reading/Mishkin13.1.pdf

[15] Ndekwu, E. C. (2013). An Analysis of The Monetary Policy Transmission Mechanism and The Real Economy in Nigeria.

[16] Ojo, M. (2013). Transition to Full-Fledged Inflation Targeting: A Proposed Programme for implementation by the central Bank of Nigeria. Central Bank, Abuja, Nigeria. Occasional Paper No. 44, (June 2013).

[17] Razzak, W. (1997). The Hodrick-Prescott technique: A smoother versus a filter: An application to New Zealand GDP. Economics Letters, 57(2), 163-168.

[18] Rudebusch, G., \& Svensson, L. E. (1999). Policy rules for inflation targeting. In Monetary policy rules (pp. 203-262). University of Chicago Press.

[19] Salemi, M. K. (1999). Estimating the natural rate of unemployment and testing the natural rate hypothesis. Journal of Applied Econometrics, 14(1), 1-25.

[20] Savastano, M. A., Masson, P. R., \& Sharma, S. (1997). The scope for inflation targeting in developing countries. International Monetary Fund.).

[21] Svensson, L. E. (2000). How should monetary policy be conducted in an era of price stability? (No. w7516). National bureau of economic research

[22] Svensson, L.E.O. (2010). Inflation Targeting. National Bureau of Economic Research, NBER Working Paper No. 16654.

[23] Siklos, P. L., \& Weymark, D. N. (2009). Has Inflation Targeting Improved Monetary Policy? Evaluating Policy Effectiveness in Australia, Canada, and New Zealand. Evaluating Policy Effectiveness in Australia, Canada, and New Zealand (March 2009).

[24] World Bank group (2013). World Development Indicators 2013. World Bank online databank. The data are available at http://data.worldbank.org/indicator 